\title{
Real-Time Polymerase Chain Reaction for One-Hour On-Site Diagnosis of Pierce's Disease of Grape in Early Season Asymptomatic Vines
}

\author{
N. W. Schaad, D. Opgenorth, and P. Gaush
}

First and third authors: U.S. Department of Agriculture-Agricultural Research Service, Foreign Disease-Weed Science Research Unit, Ft. Detrick, MD 21702; and second author: California Department of Food and Agriculture, Sacramento 95832.

Accepted for publication 14 March 2002.

\begin{abstract}
Schaad, N. W., Opgenorth, D., and Gaush, P. 2002. Real-time polymerase chain reaction for one-hour on-site diagnosis of Pierce's disease of grape in early season asymptomatic vines. Phytopathology 92:721-728.

Molecular-based techniques, such as polymerase chain reaction (PCR), can reduce the time needed for diagnosis of plant diseases when compared with classical isolation and pathogenicity tests. However, molecular techniques still require 2 to 3 days to complete. To the best of our knowledge, we describe for the first time a real-time PCR technique using a portable Smart Cycler for one-hour on-site diagnosis of an asymptomatic

late (June and after) in the season and the organism is very difficult to isolate early in the season. Sap and samples of macerated chips of secondary xylem from trunks of vines were used in a direct real-time PCR without extraction of DNA. Using two different sets of primers and probe, we diagnosed PD in 7 of 27 vines (26\%) from four of six vineyards sampled 10 to 12 days after bud break in Kern, Tulare, and Napa counties of California. The diagnosis was confirmed by isolation of Xylella fastidiosa from two of the original PCR positive samples and later from symptomatic leaf petioles of four out of four vines from one vineyard that were originally PCR positive.
\end{abstract} plant disease. Pierce's disease (PD) of grape, caused by the fastidious bacterium Xylella fastidiosa, causes serious losses in grapes in California and the southeastern United States. The disease has been difficult to diagnose because typical leaf scorching symptoms do not appear until
Additional keywords: biosensor, detection, enzyme-linked immunosorbent assay, xylem tissues.
Xylella fastidiosa, the causal agent of Pierce's disease (PD) (37), causes several economic diseases, including almond leaf scorch (ALS), phony peach (PP), plum leaf scald (PLS), leaf scorch of several shade trees (sycamore, oak, elm, and maple), and citrus variegated chlorosis (CVC) $(1,21,22,30)$. The organism is classified as a single species $(22,37)$ although molecular studies show considerable genetic diversity among many of the strains including PD, PP and PLS, CVC, ALS, oleander leaf scorch, and leaf scorch of shade trees $(5-9,14,21,28)$. The taxonomy of the organism is still undefined. The PD organism has periodically caused severe losses in most grape-growing regions of Florida $(20,21)$ and California $(16,25)$. An epidemic in southern California between 1884 and 1900 destroyed 35,000 acres of grape vines and completely eliminated grape production in the Temecula region, southeast of Los Angeles (16). The disease was first described in Anaheim, CA, in 1892 by Pierce (27) and several years later was shown to be transmitted by leafhopper insects (17). The recent introduction of the highly mobile glassy-winged sharpshooter into the state is expected to increase the spread of PD (31). In 1978, the true causal organism was cultured in vitro and shown to be a very thin $(0.2$ to $0.4 \mu \mathrm{m})$, fastidious, gram-negative bacterium by Davis et al. (11). The organism takes 6 to 10 days to form visually recognizable colonies on specialized agar media $(4,10,12,22)$, and pathogenicity tests require 1 to 2 months $(11,22)$.

The disease has been difficult to diagnose because symptoms (typical leaf scorching) do not appear until late (June and after) in

Corresponding author: N.W. Schaad; E-mail address: schaad@ncifcrf.gov

Publication no. P-2002-0508-01R

This article is in the public domain and not copyrightable. It may be freely reprinted with customary crediting of the source. The American Phytopathological Society, 2002. the growing season $(18,20)$, and the pathogen is very difficult to isolate early in the season $(11,20,35)$. Enzyme-linked immunosorbent assay (ELISA) $(22,25)$ has been useful for diagnosis of PD late in the season (35), but it lacks the sensitivity to work well early in the season. Although classical polymerase chain reaction (PCR) techniques that are 100-fold more sensitive than ELISA are available for diagnosis of PD $(2,24,35)$, ELISA is still the preferred method. Diagnosis of plant diseases has been aided greatly by the development of PCR-based techniques (15), and PCR primers are available for many important plant pathogenic bacteria (34). Although PCR techniques can reduce considerably the time needed for diagnosis compared with isolation and pathogenicity tests, they are still quite involved and time consuming. Classical PCR techniques usually require 2 to 3 days when Southern blot hybridization steps are included for confirmation of the PCR products. Real-time PCR systems, such as TaqMan (Applied Biosystems, Foster City, CA), which are based on hybridization of specific probe sequences, are available for several plant pathogens $(13,32,33,36)$. Such techniques combine the high sensitivity of PCR with the high specificity of nucleic acid hybridization, and are completed within 2 to $3 \mathrm{~h}$. However, the equipment for such systems is quite expensive and is not mobile. We investigated onsite PCR techniques for rapid diagnosis of plant diseases with a portable real-time Smart Cycler TD system (26) (Cepheid, Sunnyvale, CA) that was developed for rapid detection of human pathogenic bacteria directly in the field $(3,26,29)$. PD of grape was chosen as a model plant disease for testing the Smart Cycler system under field conditions because the pathogen is often latent $(20,21)$ and individual plants represent a considerable investment.

Our objective was to describe the use of a portable real-time PCR system for on-site diagnosis of a latent plant disease that can be completed within 1 to $2 \mathrm{~h}$. By confirming field diagnosis with a 
second set of real-time primers and probe, PD was diagnosed in asymptomatic vines in four of six vineyards and 9 of 40 samples. The technique should prove useful to growers for mapping primary sites of PD infection in vineyards during the dormant season so vines infected in previous seasons can be rogued out prior to symptom development in order to prevent the possible spread of $\mathrm{PD}$ by glassy-winged sharpshooter insect vectors during the next growing season.

\section{MATERIALS AND METHODS}

Bacterial strains and media. The following strains of Xylella fastidiosa and other bacteria were used in this study: PD strains 35879 and 35881 (American Type Culture Collection [ATCC]), 3SV10, 94-4, and 95-3; ALS 35870 (ATCC); PP4\#5; PLS2\#6; oak leaf scorch (OLS) 92-6, 92-3, and 35874 (ATCC); and periwinkle wilt (PW) 35878 (ATCC) were obtained from C. J. Chang, University of Georgia, Griffin. CVC strains 03-06L, 120-40B, and 09$02 \mathrm{~N}$ were obtained from J. R. S. Lopes, University of Sao Paulo, Brazil. Xylophilus ampelinus strains FJ-8, -28, and -44 were obtained from K. Serfontein, Pretoria, South Africa, and strain PJ-8 from P. Psallidas, Athens, Greece. Xanthomonas campestris pv. campestris (Xanthomonas campestris) strain FB-1000 was isolated from cabbage in 1998 (N. W. Schaad). Seven strains of unknown saprophytic bacteria (N. W. Schaad) were isolated in April 2000 from grape sap collected from vines in vineyards near Bakersfield (strains FJ-14, -17, -18, and -20) and Madera, CA (strains FJ-34, -36, and -39) also were included. All Xylella cultures were maintained by monthly transfers onto PD-2 agar medium $(12,22)$ at $28^{\circ} \mathrm{C}$ and stored long term at $80^{\circ} \mathrm{C}$ in $50 \%$

\section{$\mathbf{A}$}

\section{Xf ITS Oligonucleotides}

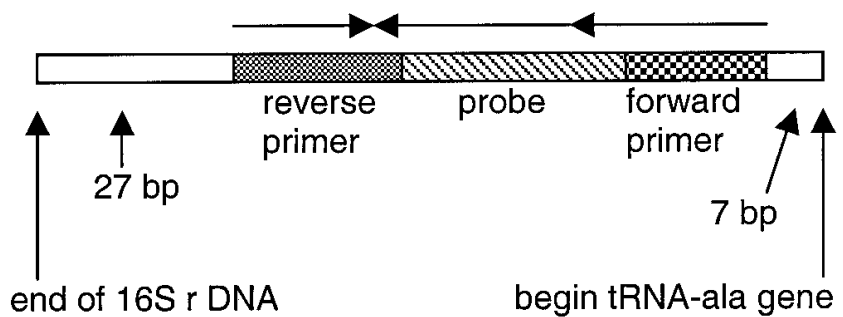

B

\section{Xf $16 S$ Oligonucleotides}

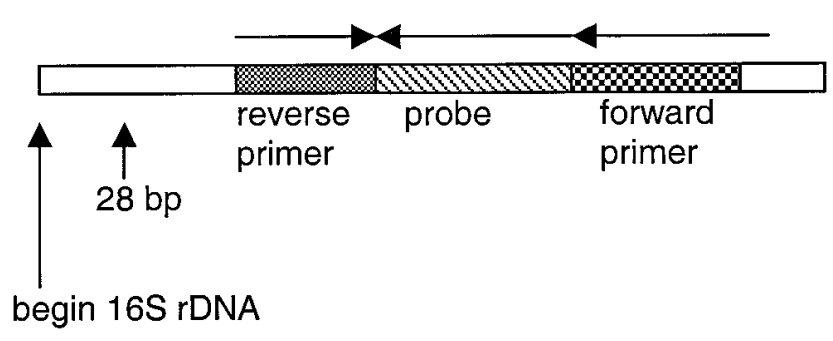

Fig. 1. Location of primers and probes. A, 16S-23S rDNA spacer region containing the Xylella fastidiosa (Xf) internal transcribed spacer (ITS) oligonucleotides and $\mathbf{B}, 16 \mathrm{~S}$ rDNA containing the Xf $16 \mathrm{~S}$ oligonucleotides. glycerol and 50\% PD-2 broth. Cells of Xylella fastidiosa strains were prepared by growing the bacteria in liquid PD-2 medium for 6 to 8 days or washing plates with water, saline, or water and saline. Field isolations were made on PD-2 and PW (10,22) agar medium supplemented with $250 \mu \mathrm{g}$ of cycloheximide per $\mathrm{ml}$ (Sigma Chemical, St. Louis).

Designing of PCR primers and fluorescent probes. PCR primers and probe sequences were designed with the primer design software program (Primer Express 1.0; Perkin-Elmer Applied Biosystems) from Xylella fastidiosa 16S rDNA and 16S-23S internal transcribed spacer (ITS) region sequences obtained from GenBank accessions. Several combinations of forward and reverse PCR primers and fluorescent probes were tested using Xylella fastidiosa strains 35879 and 95-3 and Xanthomonas campestris FB-1000, as described below. The following DNA sequences were selected for specificity to the genus Xylella according to the results of a basic local alignment search tool (BLAST) DNA similarity search, within 16S and 16S-23S ITS regions (Fig. 1): ITS forward primer XfF1, 5' AAA AAT CGC CAA CAT AAA CCC A 3'; ITS reverse primer XfR1, 5' CCA GGC GTC CTC ACA AGT TAC 3'; 16S forward primer XfF2, 5' CTC GCC ACC CAT GGT ATT ACT AC 3'; 16S reverse primer XfR2: 5' CTG GCG GCA GGC CTA AC 3'; ITS probe XfP1, 5' 6-carboxy-fluorescein (FAM) ACC TAT GCC AAC ATC AAA CCC TGA ATG CA 6-tetramethylrhodamine (TAMRA) 3'; and $16 \mathrm{~S}$ probe XfP2, 5' 6FAM ATG TGC TGC CGT CCG ACT TGC ATG TAMRA 3'.

Real-time PCR conditions. For PCR, $1.0 \mu \mathrm{l}$ of plant sap or macerate of secondary xylem tissue was added to $24 \mu \mathrm{l}$ of master mix containing $10 \mathrm{mM}$ Tris- $\mathrm{HCl}(\mathrm{pH} 8.3), 50 \mathrm{mM} \mathrm{KCl}, 5 \mathrm{mM}$ $\mathrm{MgCl}_{2}, 200 \mu \mathrm{M}$ each dNTP, $1 \mu \mathrm{M}$ forward primer, $1 \mu \mathrm{M}$ reverse primer (Life Technologies, Rockville, MD), 400 and $200 \mathrm{nM} \mathrm{5'}$ 6FAM-labeled 3' TAMRA-labeled 16S and ITS probes (Applied Biosystems), 1.25 units of AmpliTaq DNA polymerase, 1.25 units of $1 \times$ additive reagent $(1.7 \mathrm{mM}$ Tris, $\mathrm{pH} 8.0,150 \mathrm{mM}$ trehalose, $1 \%$ Tween 20 , and $1 \mathrm{mg}$ of nonacetylated bovine serum albumin [BSA] per ml [Cepheid]), and sterile molecular biology grade water to a total volume of $24 \mu \mathrm{l}$. The reactions were initiated by addition of $1 \mu \mathrm{l}$ of sample. All PCR reactions were performed in $25-\mu l$ tubes (Cepheid) in a Smart Cycler TD System. All field PCR reactions were run as follows: $95^{\circ} \mathrm{C}$ for $30 \mathrm{~s}, 40$ cycles at $95^{\circ} \mathrm{C}$ for $1 \mathrm{~s}$, and $62^{\circ} \mathrm{C}$ for $20 \mathrm{~s}$. The total time for the PCR assay, including preparation and addition of each set of 14 samples and two controls, was between 30 to 90 min for sample collection and preparation and $20 \mathrm{~min}$ for PCR.

Optimization of PCR primers and probe. Starting with an annealing temperature of $55^{\circ} \mathrm{C}$ and the above cycling parameters, all 12 Xylella fastidiosa strains tested positive using both sets of primers and probes. The optimum $\mathrm{Mg}^{++}$concentration was $5 \mathrm{mM}$. Using the unique ability of the Smart Cycler to program different annealing temperatures for each of the 16 chambers in the same run, annealing temperatures of $58,60,62$, and $64^{\circ} \mathrm{C}$ were tested simultaneously on $1-\mu \mathrm{l}$ aliquots of the same cell suspension of strain PD 95-3. The most stringent temperature that gave the highest endpoint fluorescence was chosen $\left(62^{\circ} \mathrm{C}\right)$ although generally there was little variation in endpoint fluorescence. No variation in cycle threshold $(\mathrm{Ct})$ values was observed with different annealing temperatures. The $\mathrm{Ct}$ value is defined as the PCR cycle number at which time the signal (fluorescence) of the probe rises above background. No optimization of primer concentration was performed. Primers were used at the maximum concentration for TaqMan assays as recommended by manufacturer (900 to 1,000 nM).

Specificity and sensitivity of primers and probes using pure cultures. For initial specificity testing, we included 14 strains of Xylella fastidiosa, including five PD strains, three CVC strains, three OLS strains, and single strains each for PP, PLS, PW, and ALS. Each strain was grown for 12 to 14 days on PD-2 and a portion of growth was transferred to a microfuge tube and resuspend- 
ed in $50 \mu$ of water. No attempt was made to normalize concentrations. Other bacteria tested included cells of 12 unknowns isolated in April 2000 from grape sap collected from vines near Bakersfield (FJ-14 to -20) and Madera (FJ-34 to -39) and DNA of the closely related Xanthomonas campestris FB-1000. To determine sensitivity of the real-time PCR assays, DNA was purified from a 7-day-old 10-ml liquid culture of strain 35879 with a DNA isolation kit (Puregene D-5000A; Gentra Systems, Minneapolis, $\mathrm{MN})$. The DNA concentration was determined with a Smart Spec 3000 (Bio-Rad, Hercules, CA), and 10-fold dilutions were made from $1 \mathrm{ng} / \mu \mathrm{l}$ to $1 \mathrm{fg} / \mu \mathrm{l}$. For viable cell sensitivity of the PCR assay, cultures were grown in PD-2 broth for 6 days, adjusted to 0.1 optical density at $600 \mathrm{~nm}$, and diluted serially in water or saline 10 -fold to $10^{-8}$. One hundred microliters of $10^{-2}$ to $10^{-8}$ dilutions was plated in triplicate onto PD-2 medium, and the plates were incubated at $28^{\circ} \mathrm{C}$ for 14 days for colony counts. The original dilutions were frozen at $-20^{\circ} \mathrm{C}$ for subsequent PCR assays. Samples were scored PCR positive if the second derivative of fluorescence was three times greater than the standard deviation of the mean baseline second derivative within 40 cycles, as recommended (L. Western, personal communication, Cepheid). The second derivative measures the greatest rate of change in the slope of the fluorescent growth curve (Cepheid Smart Cycler Manual).

Detection of Xylella fastidiosa: field sites and sampling. Sampling and field collections were timed to coincide with natural sap flow to make sampling more uniform and less labor intensive. Field samples were collected in California from 8 to 11 April, which was 10 to 14 days after bud break, depending upon the cultivar and location. Samples were taken from vines in vineyards in three areas of the southern San Joaquin Valley (Exeter, Bakersfield, and McFarland) and from vines in three vineyards in Napa Valley, two of R. Mondavi and one of Beaulieu. The Exeter vineyard was selected because it expressed a general decline and many vines with scorched leaves typical of PD were noted in fall 2000 (D. Opgenorth, personal observation). The Sunview vineyard in McFarland was chosen because of its history of PD-like symptoms. Also, ELISA testing in the fall of 2000 had shown the presence of PD in the Sunview vineyard (G. Wittenborn, personal communication). In Napa Valley, the Beaulieu and Mondavi Wappo vineyards were known to contain PD. No PD had been reported in the Bakersfield vineyard, a Red Globe vineyard near McFarland, and R. Mondavi's To Kalon vineyard near Rutherford. Samples from the Exeter vineyard were collected in late afternoon of 8 August and PCR tests were run the following morning. Samples from the Bakersfield and McFarland vineyards were tested by PCR within $2 \mathrm{~h}$ of collection. Sap was running in the vines in the Exeter vineyard but not in those sampled at the Bakersfield and McFarland locations. At Rutherford, all vines were sampled in late afternoon on 11 April and PCR tests were run the following morning. Sap was running in most but not all vines. The Wappo (R. Mondavi) vineyard was located along a creek, and PD was suspected of being present in vines nearest the creek. All vines chosen for sampling from the vineyards known to contain PD expressed delayed growth (2 to $10 \mathrm{~cm}$ of new growth). Adjacent or nearby healthy vines normally had 5 to $15 \mathrm{~cm}$ of new growth. Such symptoms suggest a weak vine, which is typical of vines infected 1 to 2 years previously (12). Most samples were taken from the trunk. The loose outer bark was removed with a knife and the exposed xylem tissue flamed (95\% ethanol) briefly. A 3 - to 5-cm longitudinal slit into the xylem tissue was made with a flamed knife or 3- to 4-cm chisel and if the sap flowed, a disposable 26-gauge needle attached to a 3-ml syringe was used to collect 1 to $2 \mathrm{ml}$ of liquid. If the sap was not flowing, chips of xylem tissue were removed with a flamed chisel and placed into a heavy duty ziplock plastic bag. In some cases, both types of samples were taken. All implements used for collecting samples were flamed with $95 \%$ ethanol between vines. For spur samples, the bark was flamed, the tip of the shoot was cut off, and sap was collected in a syringe as described previously. If no sap was flowing, small pieces of xylem tissue were removed with a sterile scalpel and placed into an empty plastic bag. Samples were kept on ice or in a refrigerator until they were ready for the PCR tests.

Detection of Xylella fastidiosa: on-site PCR testing. On-site is defined as within 3 to 5 miles of a field laboratory or office. For the on-site PCR testing, we chose the 16S PCR primers and probes based on preliminary data showing them to be slightly more sensitive than the ITS PCR primers and probe. Because of the additional time needed to run a second PCR reaction, we decided not to include the ITS PCR primers and probes under field conditions but to use them in later confirmatory laboratory tests. The xylem chip samples were macerated in 0.5 to $1.0 \mathrm{ml}$ of PCR grade sterile water in a double, heavy-duty plastic bag, with a hammer. A total of 200 to $500 \mu \mathrm{l}$ was transferred to a microfuge tube and stored on ice. Each PCR run contained a negative (water) and positive control (suspension containing $10^{6}$ to $10^{7} \mathrm{CFU}$ of Xylella fastidiosa strain 35879) and 14 samples of macerated tissue or sap. All field samples were taken to Sacramento on 12 April and stored at $4{ }^{\circ} \mathrm{C}$. Remaining samples were sent on 17 April by overnight U.S. mail to Fort Detrick, MD. For each field sample tested by PCR, $100 \mu \mathrm{l}$ was plated onto single plates of PD-2 and PW agar supplemented with $250 \mu \mathrm{g}$ of cycloheximide per ml within $6 \mathrm{~h}$ on the same day or by the following morning. All plates were taken to Fort Detrick and placed in an incubator at $28^{\circ} \mathrm{C}$. After 10 to 14 days, all plates were observed under a binocular microscope at $\times 50$ to $\times 75$ for typical colonies. Suspect colonies of Xylella fastidiosa ( 0.1 to $0.2 \mathrm{~mm}$ ) were transferred with a loop to a PD-2 plate and examined after 7 to 10 days at $28^{\circ} \mathrm{C}$ for typical PD colonies. All original isolation plates were retained for 28 to 30 days before being discarded, as suggested (22).

Detection of Xylella fastidiosa in subsequent laboratory tests and confirmation of field tests. To confirm results of the original field testing, using $16 \mathrm{~S}$ primers and probes, all samples from each vineyard were tested 10 to 15 days later under laboratory conditions by using both $16 \mathrm{~S}$ and ITS primers and probe. Only those samples that were positive in both the field tests and laboratory ITS assays were considered positive. Xylella fastidiosa cells

TABLE 1. Cycle threshold values of several Xanthomonas, Pseudomonas, Acidovorax, Ralstonia, Agrobacterium, Erwinia, and Clavibacter species in a multiplex assay using $16 \mathrm{~S}$ and internal transcribed spacer (ITS) primers and probe ${ }^{\mathrm{a}}$

\begin{tabular}{lcc}
\hline & \multicolumn{2}{c}{ Cycle threshold } \\
\cline { 2 - 3 } Strain & $16 \mathrm{~S}$ & ITS \\
\hline Xanthomonas campestris (FB 1000) & 38.5 & - \\
Xanthomonas uppalii (FB 639) & 31.7 & - \\
Xanthomonas pelargonii (FB 1019) & - & - \\
Xanthomonas phaseoli (FB 1023) & - & - \\
Xanthomonas cassavae (FB 1241) & - & - \\
Xanthomonas pruni (FB 1145) & 32.7 & - \\
Xanthomonas citri (FB 1196) & 30.8 & - \\
Xanthomonas hyacinthi (FB 1245) & 16.1 & - \\
Xanthomonas citrumello (FB 1262) & - & - \\
Xanthomonas aurantifolii (FB 1264) & 31.8 & - \\
Pseudomonas syringae pv. phaseolicola (FC 354) & 31.9 & - \\
P. marginata (ICPB PM12, FC 365) & - & - \\
Acidovorax avenae subsp. citrulli (FC 513) & - & - \\
Ralstonia solanacearum (FC 539) & - & - \\
Erwinia amylovora (FE 21) & 34.1 & - \\
Clavibacter iranicus (FH 48) & - & - \\
Agrobacterium tumefaciens (ICPB TT 135) & - & - \\
\hline
\end{tabular}

a A hyphen indicates a negative result (no fluorescence after 40 cycles). A minimum of $8 \mathrm{ng}$ of DNA or unquantified cell suspensions was used as samples in this assay. Culture codes beginning with FB, FC, FE, and FH are from the USDA collection of phytopathogenic bacteria in Fort Detrick, MD; ICPB, International Collection of Phytopathogenic Bacteria, Fort Detrick, MD. 
(35879) and water were used as a positive and negative control for each PCR, respectively. An ELISA (25) test also was performed on some samples because ELISA has been the standard method used for PD diagnosis (35). Double-antibody sandwich-ELISA test kits were used according to the manufacturer (AGDIA, Inc., Elkhart, IN). A reaction was considered positive if the mean absorbance was greater than the buffer control plus four times the standard deviation, as recommended (24).

Further attempts to confirm the presence of Xylella fastidiosa in several of the original sampled vines were made in July to allow for the bacterial titer to increase $(11,20,35)$. Leaf petiole samples were obtained from PCR positive vines 69-1, 71-2, 93-1, and 89-4 from the McFarland vineyard and from the two negative Red Globe vines. Vine 80-4 could not be sampled because it had died sometime after the original April sample was taken. All samples were collected and mailed overnight by Federal Express to Fort Detrick (G. Wittenborn). Upon arrival, each petiole was surfacedisinfested with a 1:10 dilution of household bleach, washed in sterile water, and cut into sections 3 to $4 \mathrm{~cm}$ in length. Each section was squeezed with a sterile flat forceps with the resulting exuded droplet placed into a microfuge tube for direct PCR and the stem end was touched six to eight times onto PD-2 agar for isolation. All suspect colonies were transferred with a toothpick to a PCR tube and the identity was confirmed by PCR. All PCR and ELISA assays were done in duplicate.

\section{RESULTS}

Specificity and sensitivity of primers and probes using pure cultures. All strains of Xylella fastidiosa tested positive with the ITS and $16 \mathrm{~S}$ probes. The strains and $\mathrm{Ct}$ values obtained with the $16 \mathrm{~S}$ and ITS probes, respectively, are as follows: grape strains ATCC 35879 (23.0, 21.9), ATCC 35881 (26.1, 24.1), PD 95-3 (23.1, 26.0), and PD 94-4 (26.4, 24.9); ALS strain ATCC 35870 (25.8, 22.4); PLS strain plum 2\#6 (25.3, 21.9); PP strain peach 4\#5 (21.4, 23.1), CVC strains 03-06L (22.6, 23.2), 120-40B (26.8, $25.2), 17.190(24.3,21.6)$, and $09.02 \mathrm{~N}(22.6,19.6)$; OLS strains 92-6 (22.7, 23.0), 92-3 (27.5, 22.0), and ATCC 35874 (19.2, 20.6); and PW strain ATCC 35878 (20.2, 25.0). One of the 12 unknown grape saprophytes (FJ-39) and Xanthomonas campestris FB-1000 DNA gave weak positive reactions $(\mathrm{Ct}=37$ to 38.5) against the $16 \mathrm{~S}$ primers and probe. None of the saprophytic bacteria or Xanthomonas campestris reacted with the ITS primers and probe. To further evaluate the specificity of the PCR assay, both $16 \mathrm{~S}$ and ITS primers and probes were screened against DNAs or cell suspensions of seven other bacteria including single strains of Ralstonia solanacearum, Acidovorax avenae subsp. citrulli, Clavibacter iranicas, and 10 additional Xanthomonas spp. These xanthomonads were included because some are closely related to Xylella (37). Also, a Ct of 38.5 resulted when Xanthomonas campestris strain FB-1000 was tested during the original selection of $16 \mathrm{~S}$ primers. For additional specificity screening, we used a mixture of $16 \mathrm{~S}$ and ITS oligonucleotides in a multiplex PCR reaction. The composition of the multiplex master mix and remaining protocol was the same as that described for the single probe reactions, except $400 \mathrm{nM} 5^{\prime}$-Cal Red, 3'-BHQ2 $16 \mathrm{~S}$ probe, and $200 \mathrm{nM}$ of the aforementioned FAM-TAMRA ITS probe were used. The Cal Red-labeled 16S probe signal was analyzed on channel 4 of the Smart Cycler device, whereas the FAM-labeled ITS probe was analyzed on channel 1 . None of the additional strains reacted with the ITS primers and probe. However, 6 of the 10 xanthomonad strains and two other bacteria resulted in $\mathrm{Ct}$ values ranging from 30.8 to 38.5 with the $16 \mathrm{~S}$ primers and probe; one strain, Xanthomonas hyacinthi, gave a Ct value of 16 (Table 1).

A suspension of Xylella fastidiosa containing $1.2 \times 10^{3} \mathrm{CFU} / \mathrm{ml}$ $(1.2 \mathrm{CFU} / \mu \mathrm{l})$ resulted in $\mathrm{Ct}$ values of 36.8 and 36.4 with ITS and $16 \mathrm{~S}$ primers, respectively. The $16 \mathrm{~S}$ primers and probe were chosen for the field diagnosis because of their slightly higher sensitivity. The threshold for DNA was $10 \mathrm{fg}$ for both $16 \mathrm{~S}$ and ITS primers and probe, and the $\mathrm{Ct}$ values were both 36.2 (Fig. 2).

Detection of Xylella fastidiosa in field samples by original field testing. Based on the $16 \mathrm{~S}$ primers and probe alone, PD was diagnosed in all six vineyards tested (Table 2). Seventeen of twenty-six vines $(65 \%)$ and 23 of 42 samples $(55 \%)$ tested were positive. In the Exeter vineyard, three of five vines were positive and the $\mathrm{Ct}$ values ranged from 28.8 to 37.0 (Table 2). In the Bakersfield vineyard, 3 of 10 samples and three of seven vines were positive but all had high $\mathrm{Ct}$ values of 35 to 38 (Fig. 3; Table 2). In the McFarland vineyard, five samples were positive (Fig. 3). No sap was available from any vines sampled in the McFarland vineyard. Samples from the two vines in the nearby Red Globe vineyard, which did not contain PD, were negative. In the Napa Valley (Table 2), three of four vines in the Beaulieu vineyard, both vines in the Mondavi Wappo vineyard, and the single vine in the Robert Mondavi To Kalon vineyard were positive, and $\mathrm{Ct}$ values ranged from 21.2 to 37.0. The $\mathrm{Ct}$ values for the positive controls ranged from 25.5 to 25.8 for each PCR run, and the water controls were always negative.

The PD organism was isolated from only one vine, Exeter 3-18 (Table 2). Both diluted and undiluted samples were positive by PCR with Ct values of 28.8 and 29.9, suggesting high titers of Xylella fastidiosa. A single colony was cloned, maintained by weekly transfers on PD-2, and archived at $-80^{\circ} \mathrm{C}$ as strain FK-14. Strain FK-14 was positive by PCR with both sets of primers and probe and produced typical PD symptoms after 60 days when Cabernet Sauvignon plants were inoculated. The number of sapro-

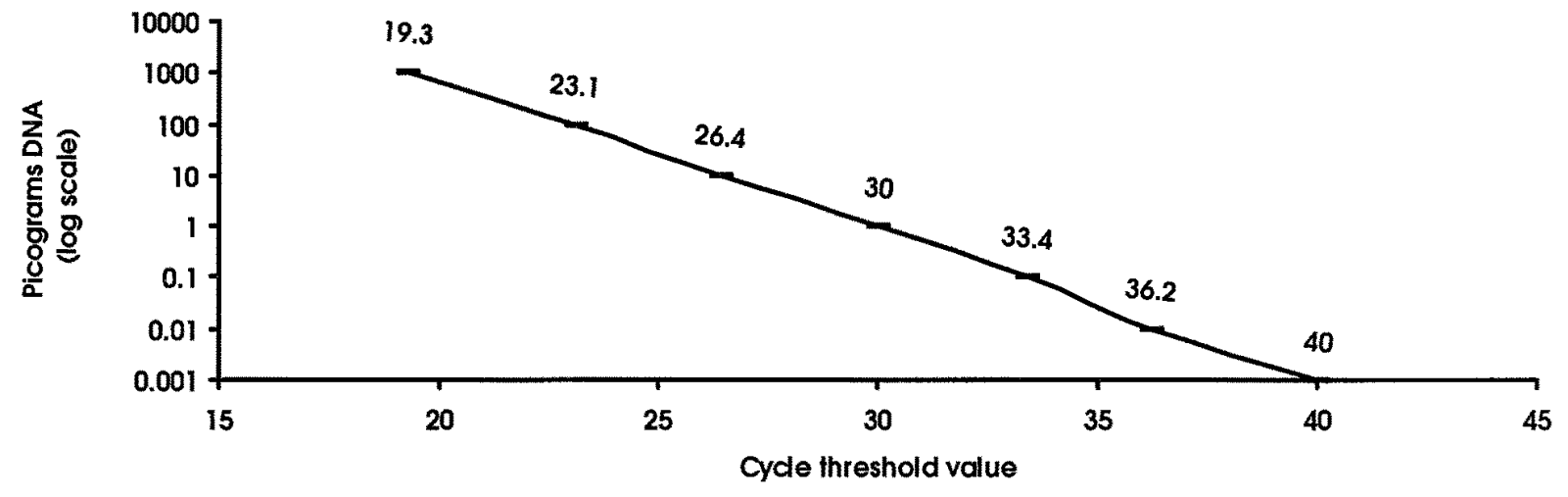

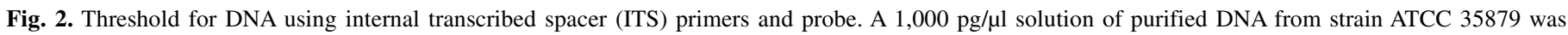

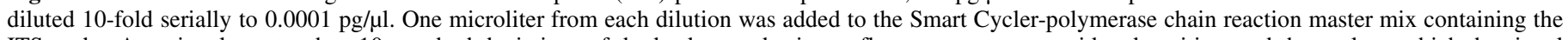

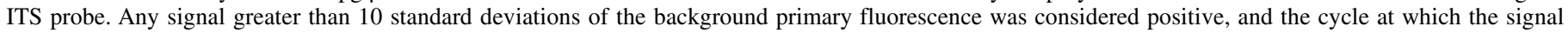
exceeded the background fluorescence is the cycle threshold reported. 
phytic bacteria that grew on PW and PD-2 plates varied with the vineyard. Generally, plates from Exeter, Bakersfield, and Napa contained fewer than $50 \mathrm{CFU}$. Because the McFarland agar plate samples contained very large numbers of saprophytes (100 to $500 \mathrm{CFU}$ per plate), it was difficult to identify any suspect colonies of Xylella fastidiosa.

To determine if any of the saprophytic colonies isolated on the media might have resulted in a false-positive reaction with our $16 \mathrm{~S}$ primers and probe, 10 visually different colony types were selected from agar plates of samples that were PCR positive. Each colony type was grown on PD-2, and a cell suspension was tested by PCR using the $16 \mathrm{~S}$ primers and probe. All were negative except one of the saprophytes in sample 10 from Bakersfield, which resulted in a $\mathrm{Ct}$ of 38.5 .

Detection of Xylella fastidiosa in subsequent laboratory tests and confirmation of field tests. Nine of the twenty (45\%) field samples that tested positive with $16 \mathrm{~S}$ primers and probe also were confirmed to be positive in later laboratory PCR tests using ITS primers and probe (Tables 2 and 3). Only those nine samples were therefore considered positive. The original field PCR tests and the subsequent tests using ITS primers and probe yielded similar results $(+$ or - ), with $73 \%$ agreement over all the vineyards (Table

TABLE 2. Diagnosis of Pierce's disease in grape samples from six vineyards in California

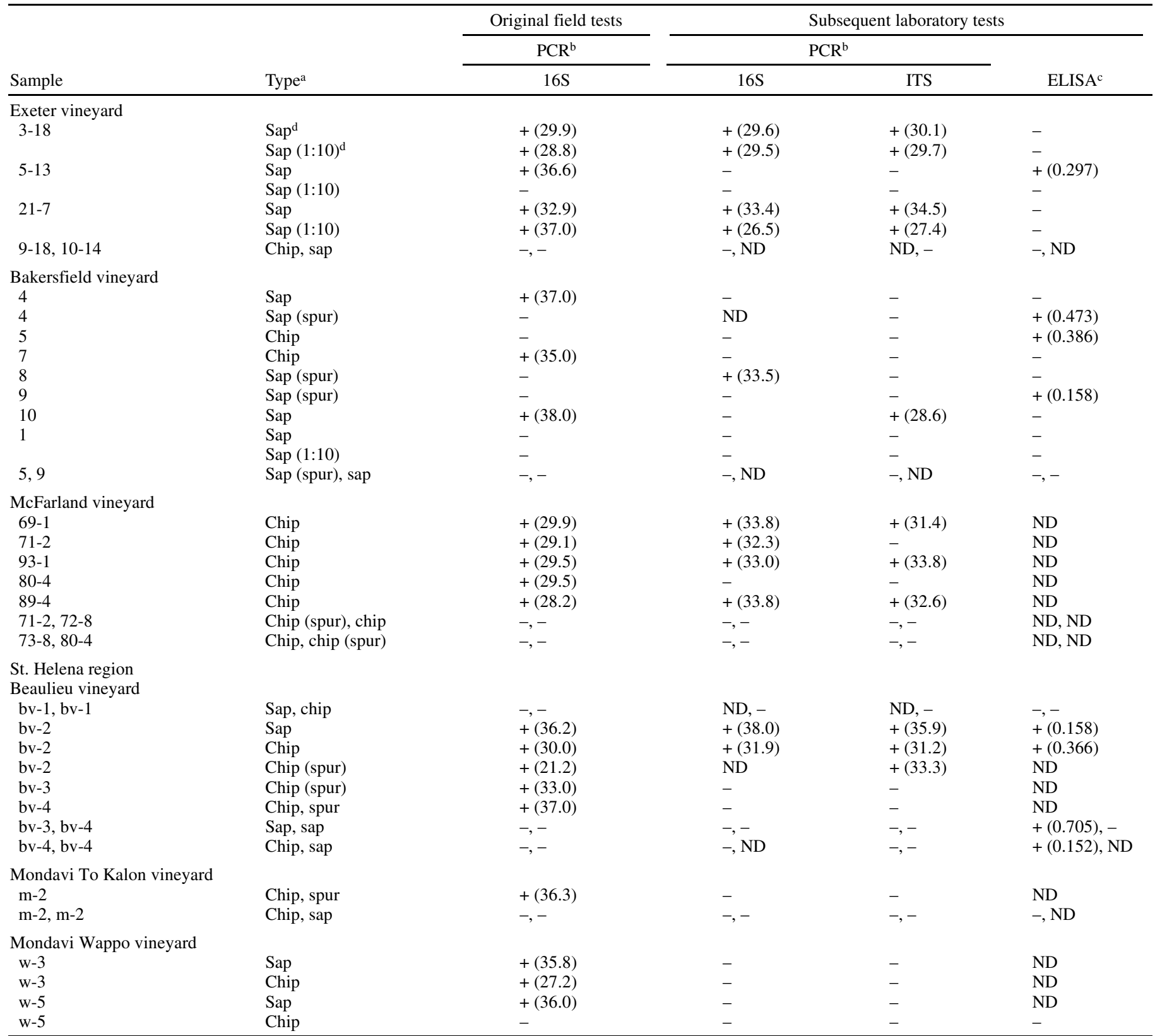

${ }^{\text {a }}$ Chip; chips of older secondary xylem tissue were macerated by pounding in a heavy duty plastic bag with a hammer and adding 0.5 to $1.0 \mathrm{ml}$ of buffer; sap; sap was removed from the secondary xylem of the trunk with a 3-ml syringe; $1: 10$ dilutions of sap were made by adding 0.1 to $0.9 \mathrm{ml}$ of water; spur, last seasons growth. St. Helena included the following three vineyards: bv, Beaulieu; m, Mondavi To Kalon; and w, Mondavi Wappo. Dilutions of 1:10 were not counted as separate samples.

${ }^{\mathrm{b}}$ For real-time polymerase chain reaction (PCR) results, figures in parentheses are cycle threshold $(\mathrm{Ct})$ values; a number greater than 38 is negative (-) and a number of 38 or lower is considered positive (+). The lower the number the more positive. 16S and internal transcribed spacer (ITS) refer to primers and probes to $16 \mathrm{~S}$ rDNA and ITS region, respectively.

${ }^{c}$ For enzyme-linked immunosorbent assay (ELISA) results, a reaction was considered positive $(+)$ if the mean absorbance given in parentheses was greater than the buffer control plus four times the standard deviation (24). A lower figure is negative (-).

${ }^{\mathrm{d}}$ Xylella fastidiosa was isolated on PD-2 agar medium. 
2). Seven of the seventeen vines (41\%) and 8 of 23 samples (35\%) tested by ELISA were positive (Table 2).

Our attempts to confirm the PCR diagnosis by isolating from the original field samples were largely unsuccessful. This failure to isolate the organism from asymptomatic vines early in the season was, however, not unexpected. In contrast, samples of leaves and petioles symptomatic of PD collected in July from each of the four PCR positive vines (69-1, 71-2, 89-4, and 93-1) in the Sunview vineyard (vine $80-4$ died from PD) were positive by isolation. After 7 to 10 days at $28^{\circ} \mathrm{C}$, several Xylella-like colonies were observed on plates from each of the samples. The cultures were cloned, confirmed as Xylella fastidiosa by PCR using ITS primers and probe, and stored at $80^{\circ} \mathrm{C}$ as strains FK-49 (69-1), -27 (71-2), -50 (89-4), and -48 (93-1). No symptoms of PD were evident in the two vines sampled in the Red Globe vineyard and isolation, and PCR results were negative. No attempt was made to assay vines that were negative originally in the Sunview vineyard.

\section{DISCUSSION}

The ease of detection of PD by our real-time PCR assay in naturally exuding sap and woody chips of secondary xylem tissues of vines just coming out of dormancy was unexpected. Unlike the techniques used for on-site real-time field testing of blood samples $(3,29)$, we were able to use plant samples directly for PCR without extracting DNA and without adding reagents (or materials) to offset endogenous PCR inhibitors. This reduces the assay time, costs and the chance of cross-contamination of samples. The apparent lack of, or reduction of, PCR inhibition may have been due to the use of a very small sample $(1 \mu \mathrm{l})$ in the reaction mix, the presence of trehalose and BSA in the Cepheid additive reagent, or a combination of both. Possibly inhibitors do not build up in grape tissue until mid-summer. We did observe difficulties with direct PCR in July. One disadvantage of using only $1 \mu \mathrm{l}$ of sample is a lower sensitivity of the assay and a reduced chance of detecting some early infections with low titers. Our overall failure

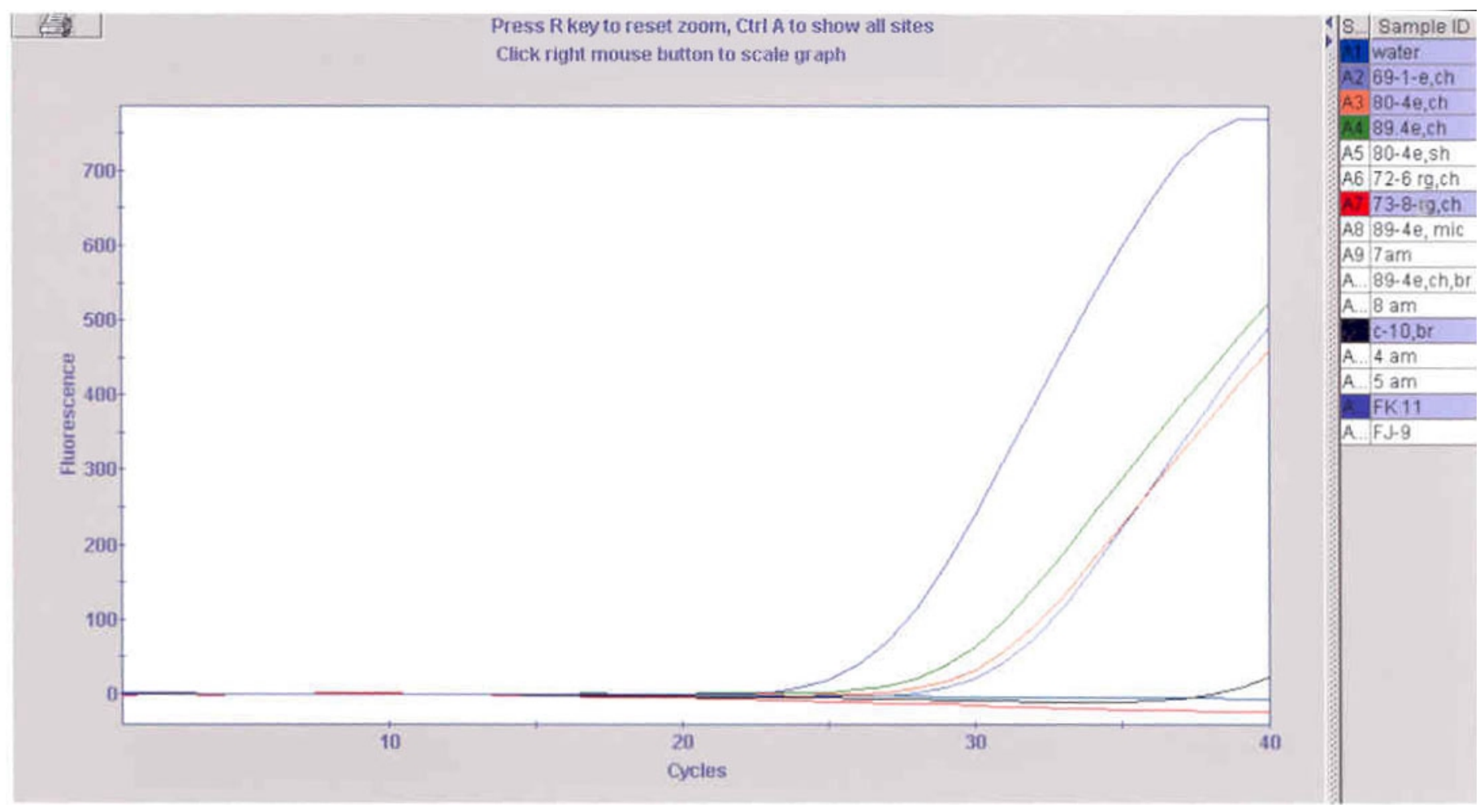

Fig. 3. Amplification of Xylella fastidiosa DNA in samples from McFarland and Bakersfield vineyards by real-time polymerase chain reaction (PCR) using the Smart Cycler detection system (Cepheid, Sunnyvale, CA) with 16S rDNA primers and probe. Left to right; positive control cells of FK-11 (ATCC 35879) (A15); positive samples 89-4 (A4), 80-4 (A3), and 69-1 (A2) from McFarland, and C-10 (A12) from Bakersfield; and negative samples of the water control (A1) and 73-8 (A7) (McFarland). The left axis $(\triangle \mathrm{RQ})$ is the change in fluorescence that measures probe cleavage and the bottom axis is the cycle number.

TABLE 3. Comparison between real-time polymerase chain reaction (PCR) results using $16 \mathrm{~S}$ primers and probe in the field and internal transcribed spacer (ITS) primers and probe in subsequent laboratory tests ${ }^{\mathrm{a}}$

\begin{tabular}{|c|c|c|c|c|c|}
\hline \multirow[b]{3}{*}{ Vineyard } & \multicolumn{5}{|c|}{ Number of samples positive/samples tested } \\
\hline & \multicolumn{2}{|c|}{$16 \mathrm{~S}^{\mathrm{b}}$} & \multirow{2}{*}{$\begin{array}{l}\text { Agreement of } 16 \mathrm{~S} \\
\text { field and laboratory }\end{array}$} & \multirow[b]{2}{*}{ ITS laboratory } & \multirow{2}{*}{$\begin{array}{l}\text { Agreement of 16S } \\
\text { field and ITS laboratory }\end{array}$} \\
\hline & Field & Laboratory & & & \\
\hline Bakersfield & $3 / 10$ & $1 / 8$ & $4 / 8$ & $1 / 10$ & $8 / 10(80 \%)$ \\
\hline McFarland & $5 / 9$ & $4 / 9$ & $8 / 9$ & $3 / 9$ & $7 / 9(73 \%)$ \\
\hline St. Helena & $9 / 18$ & $2 / 15$ & $8 / 15$ & $3 / 17$ & $11 / 12(65 \%)$ \\
\hline Total & $20 / 42(47 \%)$ & $9 / 37(24 \%)$ & $23 / 36(63 \%)$ & $9 / 40(25 \%)$ & $30 / 41(73 \%)$ \\
\hline
\end{tabular}

${ }^{a} 16 \mathrm{~S}$ and ITS are primers and probes to $16 \mathrm{~S}$ rDNA and ITS region, respectively. All samples were from field vines; 1:10 dilutions were not counted as separate samples.

${ }^{\mathrm{b}}$ Comparison between PCR conducted with $16 \mathrm{~S}$ primers and probe on-site under field conditions and later in laboratory.

c Same results, positive or negative. Only those samples tested by both $16 \mathrm{~S}$ field and $16 \mathrm{~S}$ laboratory were considered.

${ }^{\mathrm{d}}$ Same results, positive or negative. Only those samples tested by both $16 \mathrm{~S}$ field and ITS laboratory were considered. 
to diagnose PD by field isolation in asymptomatic vines that were emerging from dormancy in early April agrees with previous observations $(12,23)$. The failure to isolate the bacterium from any of the original PCR positive samples in the McFarland vineyard can be explained, in part, by the presence of numerous fast-growing saprophytes on the media. Viable cells of Xylella fastidiosa would have been overgrown by saprophytes on the isolation plates. Further evidence that the positive PCR results were not due to a false-positive PCR reaction is provided by the four positive (the other PCR positive vine, 80-4 had died) Sunview vines being positive by isolation in July. Our positive isolation and negative direct PCR results with the July samples suggest that the amount of PCR inhibitors in the tissue is much greater later in the growing season and supports our hypothesis that it is best to sample during natural sap flow in early spring.

The observed sensitivity threshold of $1 \times 10^{3} \mathrm{CFU} / \mathrm{ml}$ for our PCR assay was similar to that reported for detection of Xylella fastidiosa using classical PCR (24). However, our real-time Smart Cycler PCR assay has several important advantages over classical PCR assays $(2,24,35)$. These include use of samples directly in the PCR assay, which eliminates time-consuming DNA extractions, a more closed system, which reduces the likelihood of cross-contamination, elimination of agarose gels and subsequent Southern blot confirmation, and availability of real-time quantitative data.

The $16 \mathrm{~S}$ and ITS primers were not designed to be specific for the PD strains of Xylella fastidiosa, and all pathotype strains of Xylella fastidiosa tested positive with both sets of primers and probes. Because only the PD strain of Xylella fastidiosa is known to infect grapevines, a positive reaction should be due to the presence of the PD organism and not to any other pathotype of Xylella fastidiosa such as the PP, CVC, or ALS organism. The $16 \mathrm{~S}$ primers and probe were initially selected over the ITS primers and probe for field testing of the real-time PCR based on a slightly greater sensitivity, however, later screening of additional bacteria such as several xanthomonads and erwinae revealed a lack of specificity in the $16 \mathrm{~S}$ primers. Use of a second pair of primers and probes from a different region of the genome of Xylella fastidiosa allowed us to quickly confirm samples that were positive with the $16 \mathrm{~S}$ primers and probe. $16 \mathrm{~S}$ rDNA primers may be slightly more sensitive due to the high number of copies of the target sequence per cell, but our results clearly showed that the ITS primers are more specific. To be on the conservative side, we recommend using both the general $16 \mathrm{~S}$ and highly specific ITS primers and probe to avoid possible false-positives. Nine of twenty samples that tested positive by the original field tests with $16 \mathrm{~S}$ primers and probe were also positive later in lab tests with the ITS primers and probe. We, therefore, consider these nine samples positive based on PCR alone. Our goal in this study was to show that 1 to $2 \mathrm{~h}$ field diagnosis by PCR is possible. Adding a second PCR run only requires an extra $30 \mathrm{~min}$ and little additional costs. Alternately, samples could be tested by multiplex PCR using both sets of primers and probes, as described.

The early $\mathrm{Ct}$ values of many samples from the Sunview vineyard agree with observations from the previous fall that many vines expressed symptoms of PD and tested positive with ELISA (G. Wittenborn, personal communication). The only vine that was positive by both isolation and PCR (Exeter vine 3-18) was, however, negative by ELISA. Five of the nine samples that were positive by ELISA were negative by PCR. These most likely represent false-positives. Hill and Purcell (19) also reported false-positives for Xylella fastidiosa using ELISA. In two cases, samples that were positive by $16 \mathrm{~S}$ primers were negative by both the ITS primers and ELISA and represent false-positives. Because fewer than half of the samples were tested by both methods, it is difficult to draw firm conclusions from the ELISA results. Also, the purpose of our field tests was not to compare PCR with ELISA. Still, the results of ELISA and PCR generally agreed. More than $50 \%$ of PCR and ELISA results (both positive and negative) agreed.
To our knowledge, this is the first report detecting the fastidious PD organism in vines just coming out of dormancy. The organism is generally considered undetectable until later in the season when temperatures are consistently $27^{\circ} \mathrm{C}$ or higher and leaf scorch symptoms become evident (20-22,35). To our knowledge, this is also the first report of using a portable real-time PCR technique to diagnose a plant disease on-site within 1 to $2 \mathrm{~h}$ of collecting samples. The ability to diagnose PD in dormant vines without sending samples to a central PCR laboratory offers a huge advantage when attempting to identify and rogue out infected vines under a pest management control program. Suspect vines could be flagged in late summer and sampled any time during the normal dormant period between November and April. The collection of sap samples resulting from natural root pressure when vines are coming out of dormancy in early spring is much easier and less costly than taking chip samples when the sap is not running. If latent infected vines can be identified early in the season and rogued out before the titer of bacteria builds up, possible spread of the bacterium to other vines by insects would be greatly reduced.

\section{ACKNOWLEDGMENTS}

This research was supported in part by a loan of a Smart Cycler by Cepheid, Sunnyvale, CA. We thank B. Hutchens and P. Asahara (California Department of Food and Agriculture) for technical assistance and for assisting with the ELISA assays; J. Haskim (University of California, Extension Service), G. Wittenborn (Sunview vineyards), and J. King (Napa County Agriculture Commissioner's Office) for assisting with collection of samples and use of their facilities; G. Wittenborn for sending leaf samples for isolations; W. McMillan, R. Schaller, and L. Western for interest and technical advice; R. Frederick, V. Damsteegt, and S. Purcell for reviewing the manuscript; C. J. Chang and J. R. S. Lopes for providing cultures of Xylella; and K. Sefontein and P. Psallidas for cultures of Xylophilus ampelinus.

\section{LITERATURE CITED}

1. Almeida, R. P. P., Pereira, E. F., Purcell, A. H., and Lopes, J. R. S. 2001. Multiplication and movement of a citrus strain of Xylella fastidiosa within sweet orange. Plant Dis. 85:382-386.

2. Banks, D., Albibi, R., Chen, J., Lamikana, O., Jarret, R. L., and Smith, B. J. 1999. Specific detection of Xylella fastidiosa Pierce's disease strains. Curr. Microbiol. 39:85-88.

3. Belgrader, P., Bennett, W., Hadlye, D., Richards, J., Statton, P., Mariella, R., Jr., and Milanovich, F. 1999. Detection and identification of bacteria in 7 minutes using portable PCR instrument. Science 284:449-450.

4. Chang, C. J., and Donaldson, R. C. 1993. Xylella fastidiosa: Cultivation in chemically defined medium. Phytopathology 83:192-194.

5. Chen, J., Banks, D., Jarret, R. L., Chang, C. J., and Smith, B. J. 2000. Use of $16 \mathrm{~S}$ rDNA sequences as signature characters to identify Xylella fastidiosa. Curr. Microbiol. 40:29-33.

6. Chen, J., Jarret, R. L., Qin, X., Hartung, J. S., Banks, D., Chang, C. J., and Hopkins, D. L. 2000. 16S rDNA sequence analysis of Xylella fastidiosa strains. Syst. Appl. Microbiol. 23:349-354.

7. Chen, J. O., Lamikanra, O., Chang, C. J., and Hopkins, D. L. 1995. Randomly amplified polymorphic DNA analysis of Xylella fastidiosa Pierce's disease and oak leaf scorch pathogens. Appl. Environ. Microbiol. 61:1688-1690.

8. Coletta-Filho, H. D., Takita, M. A., DeSouza, A. A., Aguilar-vildoso, C. I., and Machado, M. A. 2000. Differentiation of strains of Xylella fastidiosa by a variable number of tandem repeat analysis. Appl. Environ. Microbiol. 67:4091-4095.

9. DaCosta, P. I., Franco, C. F., Miranda, V. S., Teixeira, D. C., and Hartung, J. S. 2000. Strains of Xylella fastidiosa rapidly distinguished by arbitrarily primed-PCR. Curr. Microbiol. 40:279-282.

10. Davis, M. J., French, W. J., and Schaad, N. W. 1981. Axenic culture of the bacteria associated with phony disease of peach and plum leaf scald. Curr. Microbiol. 6:309-314.

11. Davis, M. J., Purcell, A. H., and Thomson, S. V. 1978. Pierce's disease of grapevines: Isolation of the causal bacterium. Science 199:75-77.

12. Davis, M. J., Purcell, A. H., and Thomson, S. V. 1980. Isolation medium for Pierce's disease bacterium. Phytopathology 70:425-429.

13. Frederick, R. D., Snyder, K. E., Tooley, P. W., Berthier-Schaad, Y., Peterson, G. L., Bonde, M. R., Schaad, N. W., and Knorr, D. A. 2000. Identification and differentiation of Tilletia indica and T. walkeri using 
the polymerase chain reaction. Phytopathology 90:951-960.

14. Hendson, M., Purcell, A. H., Chen, D., Smart, C., Guilhabert, M., and Kirkpatrick, B. 2001. Genetic diversity of Pierce's disease strains and other pathotypes of Xylella fastidiosa. Appl. Environ. Microbiol. 67: 895-903.

15. Henson, J. M., and French, R. 1993. The polymerase chain reaction and plant disease diagnosis. Annu. Rev. Phytopathol. 31:81-109.

16. Hewitt, W. B. 1953. Virus diseases of grapevines. U.S. Dep. Agric. Yearbook.

17. Hewitt, W. B., Frazier, N. W., and Houston, B. R. 1942. Transmission of Pierce's disease of grapevines with a leafhopper. (Abstr.) Phytopathology 32:8.

18. Hewitt, W. B., Houston, B. R., Frazier, N. W., and Freitag, J. H. 1946. Leafhopper transmission of the virus causing Pierce's disease of grapevines and dwarf of alfalfa. Phytopathology 36:117-128.

19. Hill, B. L., and Purcell, A. H. 1995. Multiplication and movement of Xylella fastidiosa within grape and four other plants. Phytopathology 85:1368-1372.

20. Hopkins, D. L. 1981. Seasonal concentration of the Pierce's disease bacterium in grapevine stems, petioles, and leaf veins. Phytopathology 71: 415-418.

21. Hopkins, D. L. 1989. Xylella fastidiosa: Xylem-limited bacterial pathogen of plants. Annu. Rev. Phytopathol. 27:271-290.

22. Hopkins, D. L. 2001. Xylella fastidiosa. Pages 201-213 in: Laboratory Guide for Identification of Plant Pathogenic Bacteria. 3rd ed. The American Phytopathological Society, St. Paul, MN.

23. Hopkins, D. L. 1977. Diseases caused by leafhopper-borne rickettsia-like bacteria. Annu. Rev. Phytopathol. 15:277-294.

24. Minsavage, G. V., Thompson, C. M., Hopkins, D. L., Leite, R. M. V. B. C., and Stall, R. E. 1994. Development of a polymerase chain reaction protocol for detection of Xylella fastidiosa in plant tissue. Phytopathology 84:456-461.

25. Nome, S. F., Raju, B. C., Goheen, A. C., Nyland, G., and Docampo, D. 1980. Enzyme-linked immunosorbent assay for Pierce's disease bacteria in plant tissues. Phytopathology 70:746-749.

26. Northrup, M. A., Christel, L., McMillan, W. A., Petersen, K., Pourahmadi, F., Western, L., and Young, S. 1999. A new generation of PCR instruments and nucleic acid concentration systems. Pages 105-125 in: PCR Applications-Protocols for Functional Genomics. Academic Press, San Diego, CA.

27. Pierce, N. B. 1892. The California vine disease. U.S. Dep. Agric. Div. Veg. Pathol. Bull. 2.

28. Pooler, M. R., Hartung, J. S., and Fenton, R. G. 1995. Genetic relations among strains of Xylella fastidiosa from RAPD-PCR data. Curr. Microbiol. 31:134-137.

29. Pourahmadi, F., Taylor, M., Kovacs, G. A., Lloyd, K., Sakai, S., Schafer, T., Belton, B., Western, L., Zaner, S., Ching, J., McMillan, W. A., Belgrader, P., and Northrup, M. A. 2000. Toward a rapid, integrated, and fully automated DNA diagnostic assay for Chlamydia trachomatis and Neisseria gohorrhoeae. Clinical Chem. 46:1511-1513.

30. Purcell, A. H. 1997. Xylella fastidiosa, a regional problem or global threat? J. Plant Pathol. 79:99-105.

31. Purcell, A. H., and Saunders, S. R. 1999. Glassy-winged sharpshooters expected to increase plant disease. Calif. Agric. 53:26-27.

32. Roberts, C. A., Dietzgen, R. G., Heelan, L. A., and Maclean, D. J. 2000. Real-time RT-PCR fluorescent detection of tomato spotted wilt virus. J. Virol. Methods 88:1-8.

33. Schaad, N. W., Berthier-Schaad, Y., Sechler, A., and Knorr, D. 1999. Detection of Clavibacter michiganensis subsp. sepedonicus in potato tubers by BIO-PCR and an automated real-time fluorescence detection system. Plant Dis. 83:1095-1100.

34. Schaad, N. W., Jones, J. B., and Chun, W. 2001. Laboratory Guide for Identification of Plant Pathogenic Bacteria. 3rd ed. The American Phytopathological Society, St. Paul, MN.

35. Smart, C. D., Hendson, M., Guilhaert, M. R., Saunders, S., Friebertshauser, G., Purcell, A., and Kirkpatrick, B. C. 1998. Seasonal detection of Xylella fastidiosa in grapevines with culture, ELISA and PCR. (Abstr.) Phytopathology 88(suppl.):S83.

36. Weller, S. A., Elphinstone, J. G., Smith, N. C., Boonham, N., and Stead, D. E. 2000. Detection of Ralstonia solanacearum strains with a quantitative, multiplex, real-time, fluorogenic PCR (TaqMan) assay. Appl. Environ. Microbiol. 66:2853-2858.

37. Wells, J. M., Raju, B. C., Hung, H.-Y., Weisburg, W. G., Mandelco-Paul, L., and Brenner, D. J. 1987. Xylella fastidiosa gen. Nov.: Gram-negative, xylem-limited, fastidious plant bacteria related to Xanthomonas spp. Int. J. Syst. Bacteriol. 37:136-143. 